\title{
Entry Mode Issues in the Internationalisation of South African Retailing
}

\author{
Dr. Edward A.N. Dakora \\ Faculty of Business, Cape Peninsula University of Technology \\ Cape Town, South Africa \\ Email: dakorae@cput.ac.za \\ Prof. Andy J. Bytheway \\ Faculty of Informatics and Design, Cape Peninsula University of Technology \\ Cape Town, South Africa \\ Email: andy.bytheway@gmail.com
}

Doi:10.5901/mjss.2014.v5n4p194

Abstract

The recent increase in international retail activity within Africa has plunged the continent into a retail revolution. At the forefront of this revolution are major retail chains from South Africa. Although, this increase in retail internationalization in Africa has stimulated FDI and trade within the continent, South African retailers making this move have generally been criticised for their inadequate contribution to local economies of the countries they go into. This paper explores the ways in which South African retailers expand into other African countries and the circumstances that make this process different from other parts of the world. More specifically, this paper examines how the choice of entry mode into African countries can either mitigate or further complicate the process. The paper analyses case studies of five major South African retails with operations in other African countries. In-depth interviews were undertaken with senior managers in these organisations as part of the study. The findings of this study indicate that the "mode of entry" can be used to mitigate the risks associated with retail internationalisation in Africa. The study was limited to analysis of the retail companies within South Africa, and therefore viewpoints of the target country stakeholders (local suppliers, customers, local retailers, government and others) remain to be explored in future work.

Keywords: Retailing, internationalisation, Africa, entry mode, African markets

\section{Introduction}

In recent years there has been significant increase in the internationalisation of retail activity in Africa, plunging the continent into a retail revolution. There is now a trend of new retail space developments in most African countries, and international retailers - notably South African retailers - are competing for their share of the African markets. This recent development has not only attracted South African retailers of all kinds to expand their operations further north into Africa, but has also attracted the largest retailer, Walmart, into the continent on a takeover deal with one of South Africa's largest retailers - Massmart.

Despite this move by South African retailers to invest in the rest the continent, stimulating foreign direct investment (FDI) and intra-Africa trade, they have come under scrutiny for their contribution to the local economies of the countries they operate in which is generally seen as being too little. This raises the question as to whether or not Africa is ready for a retail revolution and what the nature of such a revolution might be. The generally inadequate level of economic activity in manufacturing industries, and the extensive subsistence agriculture, limited food processing capability, and highly informal retail operations make this question much more difficult. The baseline from which this retail expansion is starting is much less well developed than in other regions of the world.

On the other hand, the South African retail environment is highly sophisticated, with advanced support from local producers and well developed supply chains. In fact, six South African retailers: Shoprite, Pick n Pay, Massmart, Metcash Trading Africa, Spar and Woolworths have been listed in the Deloitte's 2009 ranking of the top 250 global retailers (Deloitte, 2011). This suggests an imbalance between South Africa and the rest of the continent when it comes to retail development, and this imbalance often results in South Africa being seen as a "big brother", taking over the markets of other African countries in a way that has been described as "colonial" (Miller, 2008). This may require home and host country interventions to streamline trade policies and regulation. Rasiah, Gammeltoft and Jiang (2010) have 
emphasised the role of government in this regard.

The situation in the context of this study refers to the increase in the dynamic and complex nature of African markets, and the differences between the 54 countries that make up Africa. More specifically, the continent is entering an epoch of significant retail growth. This is influenced by Africa's growing middle class, its growing population, the expanding cities and the changing consumption patterns of Africans (African Development Bank, 2007). Yet there is limited infrastructural growth to match the aspirations of these growing consumer markets. Therefore, although these markets together present a unique retail opportunity for retail chains mostly from South Africa, the situation demands more than the delivery of products and services. It is the creation of a new retail experience, which may have to be achieved with as much local participation as possible.

This paper presents an exploration of the way in which major retailers from South Africa are expanding their business activities into other African countries. Of particular interest is how their choices of entry modes might mitigate the challenges and risks of doing business in other African countries. The rest of the paper is structured as follows: literature review, methodology, results, discussion, conclusion, and references.

\section{Literature Review}

This section discusses relevant literature in international business and retailing to inform the study. It particularly looks at the expansion of retailing from a global perspective, retail internationalisation within Africa, entry mode issues and some theoretical background to entry mode research.

\subsection{Global expansion of retail activity}

The dramatic growth of retail activity around the world is well reported (Park \& Sternquist, 2008, Myers \& Alexander, 2007; Dawson \& Mukoyama, 2006). The activities involved in retail internationalisation, such as sourcing products internationally, operating shops in foreign countries, using foreign labour, adopting foreign ideas and using foreign capital are now understood according to Dawson and Mukoyama (2006). Myers and Alexander (2007) aver that the rising levels of internationalisation among retail businesses can be attributed to three factors: growth in size, growth in technological sophistication, and the need to respond to changing demands and behaviours of customers. All the above attributes make the concept of retail internationalisation much wider in scope and more complex than might be seen at first sight.

Some analysis has found that retailers tend to limit their foreign operations to their home region or district (Moore \& Fernie, 2004; Nordås, Grosso \& Pinali, 2007), but others report that this is no longer the case as there has been a dramatic increase in international retail activity around the world in recent years (Dawson \& Mukoyama, 2006; Myers \& Alexander, 2007; Park \& Sternquist, 2008).

In the past decade, the African continent has seen shopping centres and malls built in most major cities, some of which are also South African investments (Miller, 2006). Despite the increase in international retail activity across Africa, led by the South African retailers, little research (with management focus) has been done in this area, making it difficult for the complexities of international retailing in the African context to be understood. Dakora, Bytheway and Slabbert (2010) propose that it is not easy getting into African markets as there are significant inherent challenges, in particular in terms of choosing the right mode of entry.

\subsection{Understanding retail internationalisation in Africa}

The internationalisation of retailing in Africa has been pioneered by South African retailers exploring the market potential of the rest of Africa, where retail markets have been characterised by large open-air markets and informal trading activities (Dakora et al., 2010). Actual retail expansion into the African continent has been led by four major South African supermarket groups Shoprite, Woolworths, Spar, and Pick $n$ Pay. This trend has led researchers to be concerned about the impact of the activities of these retailers on local suppliers, employment, and even food security (see Crush \& Frayne, 2011; Dakora, 2012a). Other South African retailers including Game (general merchandise), Pep Stores (clothing), have also expanded into the continent, and this is resulting in higher levels of competition (Miller, 2008 \& Dakora et al., 2010).

This expansion has been driven by a saturated, highly competitive and shrinking domestic market, at a time when political reforms in African countries have led to rising economic development, urbanisation and middle class incomes that demand first world retail services (Weatherspoon \& Reardon, 2003). These factors encourage expansion into new markets that present strategic opportunities for growth, especially within those South Africa retailers that are feeling the 
pressure at home. This trend of retail expansion has been in line with the global retail expansion trend, which is characterised by large retailers moving from comparatively more advanced and developed countries into less developed ones, and from urban centres to small and rural towns.

Most of the South African retail expansion into the continent has been by means of "own stores", and to a lesser extent by franchising. One view is that partnership or acquisition is difficult due to a lack of suitable partner and acquisition targets; most countries in the continent have very informal retail systems (Games, 2008). Yet another view attributes this to retail management wanting to have control of their business operations in the countries they expand into (Dakora et al., 2010). What seems clear is that the challenges and opportunities arising from different "entry modes" that achieve a presence in African markets must be understood (Dakora et al., 2010). The balance between these challenges and opportunities is what leads to the creation of value, to the benefit of all parties concerned.

\subsection{Entry mode issues}

It is argued that entry mode choice is one of the most important strategic decisions companies seeking international expansion have to make "as it involves a given level of resource commitments in different target markets with different levels of risk, control and profit return" (Ripollés, Blesa \& Monferrer, 2011:2). This is even more complex when it comes to retail internationalisation, as it adds to the issue of localisation versus standardization (Zentes, Morschett \& SchrammKlein, 2007).

The debate on standardisation versus localisation or adaptation, for that matter, has been contended by Dawson and Mukoyama (2006) in their work on the difference between international retailing and production. Dawson and Mukoyama are of the opinion that retail internationalisation has to be localised to some extent. These issues shape the internationalisation decisions and strategies of retailers, which are complex and costly (Pederzoli, 2006:415). For example, anecdotal evidence indicates that when Tesco opened their first store in Budapest in Hungary, 65000 product lines were stocked which included extensive duplication of local and "shipped-in" stock. Tesco management did this as an experiment to try and understand local buying preferences and shoppers' willingness to change them over time. This has not been the case in the internationalisation practices of South African retailers for reasons such as the inefficiency of local production systems of most African countries to supply the retailers, and the urge to promote South African products.

Early studies in the field of retail internationalisation other than in Africa have looked at various paths, modes and processes of expansion. This is because internationalising firms are not only concerned about which foreign market to enter and when to do so, but also how to venture into the new and foreign market (Zhang, Zhang \& Liu, 2007). A number of entry modes are used in the internationalisation processes of multinational corporations. These mode options include: joint-ventures or strategic alliances, fully-owned subsidiaries, exports, franchises, mergers and acquisitions, distribution networks, and licensing arrangements.

There are significant differences between these modes, and the international business literature recognises them to be somewhat industry specific, and the choice of mode in any particular instance is problematic. With no particular sector in mind, Kathuria, Joshi and Dellande (2008) classify international market entry modes into two primary categories including wholly-owned operations (acquisitions or green field developments) and collaborative operations (joint-ventures or strategic alliances). The retail sector has major constraints: while manufacturers can produce at home and simply sell their products beyond national borders, retailers must have a presence in the foreign markets in which they wish to sell (Sternquist, 2007). Of course, retailing is part of the supply chain that starts with manufacturing; as Sternquist (2007) shows; retailers have limited choices of entry mode when compared with their manufacturing counterparts.

Each mode of entry available to retailers has its own different benefits and challenges in terms of cost, speed of entry, flexibility, control, financial engagement and risk (Picot-Coupey, 2006). These benefits and challenges necessitate a trade-off between risks and returns (Kathuria, Joshi \& Dellande, 2008). To make the right choice, these risks and returns need to be understood.

\subsection{Entry mode options for retail internationalisation}

When it comes to international market entry strategies, there are always limited entry mode options available to management (Javalgi, Dixit, Deligonul \& Cavusgil, 2011). The most common entry mode options include: wholly ownedsubsidiaries, franchising, and joint ventures, and these are discussed from the perspective of retailing. 


\subsubsection{Wholly owned subsidiary}

As the name indicates, wholly owned subsidiary represents full ownership of foreign operations by companies expanding across national borders. In this arrangement the investing company owns 100 per cent of the new entity in a target country (Menipaz \& Menipaz, 2011). This entry mode has two dimensions as pointed out by Menipaz and Menipaz; in one sense the new entity can be built from scratch (green field investment), and in the other, it may be the outcome of an acquisition of a local business (cross-border acquisition).

Moreover, from a retail perspective, there is always a merger after an acquisition deal; hence the terms mergers and acquisitions are often used interchangeably and together (Pahl \& Richter, 2008). The main difference between mergers and acquisitions is contractual, in that one retailer buys the other and assumes full ownership, a majority stake in the latter, or the former, and both agree to combine their resources in establishing an entirely new entity (pure merger). International mergers are said to be the same as equity joint ventures, except that the different parties (from two different countries) "agree to integrate their operations on a relatively co-equal basis", and this leads the creation of an entirely new entity (Menipaz \& Menipaz, 2011:360).

However, acquisition-based mergers appear to be the most commonly used form of mergers in retail internationalization, as one retailer buys or takes over another and incorporates it into an existing business model; this makes it a wholly owned subsidiary (Slangen \& Hennart, 2007; Pahl \& Richter, 2008). Mergers and acquisitions are, however, used together for the purpose of this study, considering that it is in part or in full a dimension of a wholly owned subsidiary.

When it comes to South African retailers' expansion into other African countries, mergers and acquisitions are not popular due to a general lack of suitable acquisition targets, given the informal nature of the retail sector in most African countries (Games, 2008).

\subsubsection{International franchising}

A "franchise" is referred to as the right to operate a business under a company's name according to the terms of an agreement (Sternquist, 2007:138). International franchising is one of the most preferred modes of entry in the internationalization of retailing. This arrangement is considered a contractual, vertical marketing relationship between a retailer (franchisor) and one or more local entrepreneurs in different countries (franchisees) (Grünhagen, Dorsch \& Wollan, 2008). This contractual agreement allows the franchisee to use the franchisor's trade name, trademarks, business model and technology for a given geographic location and a period of time agreed upon, and the franchisor receives royalties in return (Kotabe \& Helsen, 2008).

As a mode of retail internationalization, Sternquist (2007) points out three reasons that motivate why international retailers choose franchising as: the intention to extend limited resources; a way to improve administrative efficiency; and a way to provide risk management (in this case by transferring the risk to other people). Moreover, two generic types of international franchising exist and are outlined by Sterquist as:

- Direct franchise, which is usually given to an individual store owner and individual applications are viewed separately;

- Master franchise, which concerns an individual franchisee that is given the right to expand the business model in a particular geographic area (region, state or country).

The master franchise system allows the franchisee, who is normally a local entrepreneur, to sell local franchises within that particular territory, and is therefore seen as a smarter way of capturing opportunities in foreign markets (Kotabe \& Helsen, 2008). This, then, makes the master franchise holder an intermediary between the corporate franchisor and the individual franchisees; it has been said to be the newest form of retail expansion (Sternquist, 2007).

Despite Sternquist's argument, master franchising arrangements favour the franchisor, as most of the work involved in the expansion of the operation in the international market is carried out by the master franchisee in the particular territory (Quinn \& Alxander, 2002). This makes the expansion easier and more cost effective, and, as an added advantage, Quinn and Alexander assert that the local partner understands the local market conditions better than the franchisor and is, therefore, better placed to handle local issues such as culture, language barriers, bureaucracy, red tape and other political problems.

In an earlier study, Hoffman and Preble (2004:102) indicated that "a country's regulatory framework as well as the government's actions or inactions can foster or hinder franchise development in any nation". A typical example is the Doubin Act in France, which requires companies to have owned company outlets for the first two to three years before 
embarking on franchising (Cliquet, 2000). The reverse is the case in India, where government regulations prohibit foreign ownership of retail stores. The situation in India is further highlighted in the discussion of Shoprite's internationalization in Africa (see Dakora et al., 2010).

\subsubsection{Joint ventures and strategic alliances}

In the 21st century, organizational systems are evolving to be more complex as companies across various industries realise the benefits of the global marketplace; one of the themes that emerges out of this process is the significance of partnerships and strategic alliances in achieving global presence (Wu, Shih \& Chan, 2009).

From an international retailing perspective, joint ventures and strategic alliances are business partnership arrangements between retailers based in different countries, mostly initiated by a retailer wanting to expand its operations across borders (Hollensen, 2007). Furthermore, Sternquist (2007) describes strategic alliances as business relationships established by two or more companies with mutual needs, including risk sharing and achieving common objectives. As these definitions emphasize, strategic alliance relationships must be mutually beneficial and have common goals; therefore, power and control are not necessarily important.

An international joint venture on the other hand is an agreement between two or more independent retailers in different countries, allowing them to pool their capabilities and resources together in order to operate in one country or another (Lukas, 2007). According to Hollensen (2007), the main difference between a joint venture and a strategic alliance is that a strategic alliance is typically a non-equity cooperation (it does not require financial commitment) while a joint venture can be either an equity- or non-equity-based arrangement. Therefore an international joint venture can be the same as a strategic alliance, depending on the nature of the contractual agreement. Besides that, Kotabe and Helsen (2008) add that the nature of the alliance variance may also be dependent on the skills brought in by the partners involved in any alliance relationship.

Conversely, a strategic alliance differs from other collaborative arrangements because it occurs in the context of the long-term plans and objectives to improve the competitive standing of participant companies; in this case, in international markets (Ghisi, da Silveira, Kristensen, Hingley \& Lindgreen, 2008). Strategic alliances also come in many forms based on a simple licensing arrangement at one extreme between two partners, and a web of relationships at the other (Kotabe \& Helsen, 2008). This mode has been used by new international companies to complement market entry strategies of leading global companies to facilitate their entry into the global marketplace (Mathews, 2006:14).

\subsection{Theoretical perspectives on entry mode choice}

Various theories have been used in the literature to explain nature of international business and entry mode choice. The eclectic paradigm, also known as the OLI framework is one of the most cited theories of internationalisation (Dunning, 1988). In the context of retail internationalisation, Park and Sternquist (2008) used the OLI framework to propose a model for explaining global retailers' choice between a wholly owned subsidiary and franchise as entry modes in global markets. However, the application of this framework especially in today's complex and dynamic international business environment raises some concerns. Narula (2010:36) observes that "there are more complexities to its understanding and application than are immediately obvious."

This is possibly because the OLI framework is arranged along the lines of FDI and the motivations for foreign production activities of MNCs (Dunning, 2000:164; Dunning, 2001:176), and although its application can be contextual (Dunning, Pak \& Beldona, 2007:545-6) it has limitations when it comes to entry mode choices of retailers. Moreover it does not lend itself easily to flexible and contractual entry mode options like partnership and franchising which sometimes needed for such highly complex and dynamic markets as Africa.

The stages theory (also known as the Uppsala model) (Johanson \& Wiedersheim-paul, 1975) is another theory, though originally developed to study the internationalization of manufacturing firms, informs the process of retail international expansion. According to the stages model, companies begin internationalisation by expanding into near and culturally similar markets and after gathering some experience, gradually expand into countries that are less similar and geographically far-flung (Sternquist, 2007 \& Hollensen, 2007). The stages nature of the process of internationalisation in this sense, allows for an experiential learning and incremental commitment of resources to international expansion. As Sternquist argues, the stages for retail internationalisation are based more on risk taking and knowledge accumulation rather than export. Hence, retailers begin their expansion by entering countries with less psychic distance (Asgari, Ahmad \& Gurrib, 2010). This argument resonates with the way retailers from South Africa have sought to expand into 
Africa.

Yet another theory that is often considered when making entry mode choices is transaction cost analysis to determine the costs-benefits of any given entry mode. This analysis of entry mode is always difficult to undertake, given the complexity of the international business environment and the nature of entry modes available (Anderson \& Gatignon, 1986). Transaction cost analysis can also be related to the resource-based or institutional theory. The resources and time at the disposal of the investing company can influence the company's decision to engage in a prolonged bargaining and negotiation process. This theory is concerned with the capabilities of the retail company to manage the process of internationalisation with all the complexities in attendance. The Walmart - Massmart takeover deal is a good example.

Walmart entered South Africa by acquiring Massmart, one of the largest retailers and distributors of consumer goods in Africa. This takeover deal was contested by the South African government and trade unions since its announcement in 2010, for fears that the merger would destabilise manufacturing in the economy and the country's new growth paths (Bleby, 2011). It was also claimed that the Walmart takeover deal would lead to wage cuts, and job losses. However, the world biggest retailer and its merging counterpart would not heed to "unfair" preconditions. This dragged the takeover deal on until early 2012 when the competition tribunal finally ruled in favour of Walmart and its merging counterpart, but with some conditions.

\section{Methodology}

This study was guided by the case study approach as expressed by Yin (1981, 2003, \& 2009). According to Yin, case study method allows for phenomena to be examined in their real-life contexts, especially when such phenomena and contexts exhibit no clear boundaries. Yet, Hammersley and Gomm (2000:2) argue that "all research is case study" in the sense that there is always an object of study (the unit or set of units) which determines the kind of data to be collected and analysed. As this study is context bound, dealing with South African retail companies and their expansion into the rest of Africa, an examination of the phenomenon in various case studies with this context in mind is appropriate.

The study reports the analysis of five case studies of major South African retailers which have expanded into other African countries including: Shoprite/Checkers, Woolworths South Africa, Foschini, Pick n Pay and Mr Price. These retail companies are different in the sense that, Shoprite and Pick n Pay are traditionally food retailers while Foschini and $\mathrm{Mr}$ Price are pure clothing retailers. Woolworths RSA on the other hand is made up of both clothing and food divisions. Quite recently Pick $n$ Pay and Shoprite also introducing clothing lines. These product orientations of the retailers studied have influenced their approaches to internationalization. Table 1 provides summary of the retail companies studied.

Table 1: Summary of the kind of retailers studied (at the time of the study)

\begin{tabular}{|l|l|c|}
\hline \multicolumn{1}{|c|}{ Retailer } & \multicolumn{1}{c|}{ Kind of retailer } & $\begin{array}{c}\text { No. of African } \\
\text { Countries outside SA }\end{array}$ \\
\hline Shoprite & - Food or supermarket retailer & 15 \\
\hline Pick n Pay & - Food /supermarket & 5 \\
\hline Woolworths SA & - Fashion/clothing and food retailer & 13 \\
\hline Foschini & - Fashion /clothing and accessories & 4 \\
\hline Mr Price & - Fashion/ clothing & 8 \\
\hline
\end{tabular}

Source: Dakora (2012b)

In-depth interviews were conducted with senior managers across all fives case study companies. The interviews were guided by a conceptual framework focusing on the characteristics of: the retailer, the mode of entry, and the target country (see Figure 1).

Figure 1: The basic components of the study.

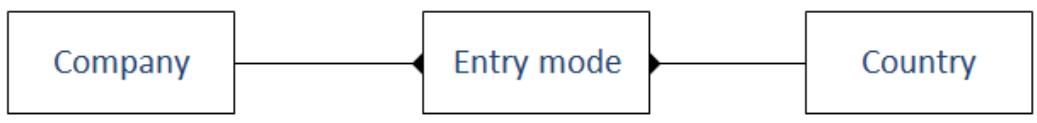

Source: Dakora (2012b) 
A total of nine interviews were conducted with the senior managers and recorded; the average length of the interviews was one hour. Table 2 presents a summary of the interviews and respondents.

Table 2: Summary of interviews and respondents

\begin{tabular}{|c|c|c|l|}
\hline No & Retail companies & Number of interviews & \multicolumn{1}{c|}{ Respondents } \\
\hline 1 & Woolworths SA & 3 & $\begin{array}{l}\text { - General manager, international franchising } \\
\text { - Manager, international supply chain } \\
\text { - Director, Good Business Journey program }\end{array}$ \\
\hline 2 & Mr Price Group & 1 & - Director, international franchising \\
\hline 3 & Foschini Group & 2 & $\begin{array}{l}\text { - Manager, supply chain } \\
\text { - Managing Director, Group Properties }\end{array}$ \\
\hline 4 & Pick n Pay & 2 & $\begin{array}{l}\text { - Director, New Enterprise Development } \\
\text { - Manager, strategy development }\end{array}$ \\
\hline 5 & Shoprite & 1 & - Director, Non RSA Operations \\
\hline
\end{tabular}

Source: Dakora (2012b)

The interviews were transcribed verbatim and the data was analysed using a Microsoft Access based "qualitative content analyser". The database (analyser) was designed around the principles of qualitative analysis originally articulated by Schutz (1959) and developed subsequently by others (Strauss \& Corbin, 1998). Transcripts were loaded into the qualitative content analyser and deconstructed in order to tease out the significance of the content by means of first and second order constructs that were then categorised for interpretation. Figure 2 shows this analysis process.

Figure 2: The interview analysis process

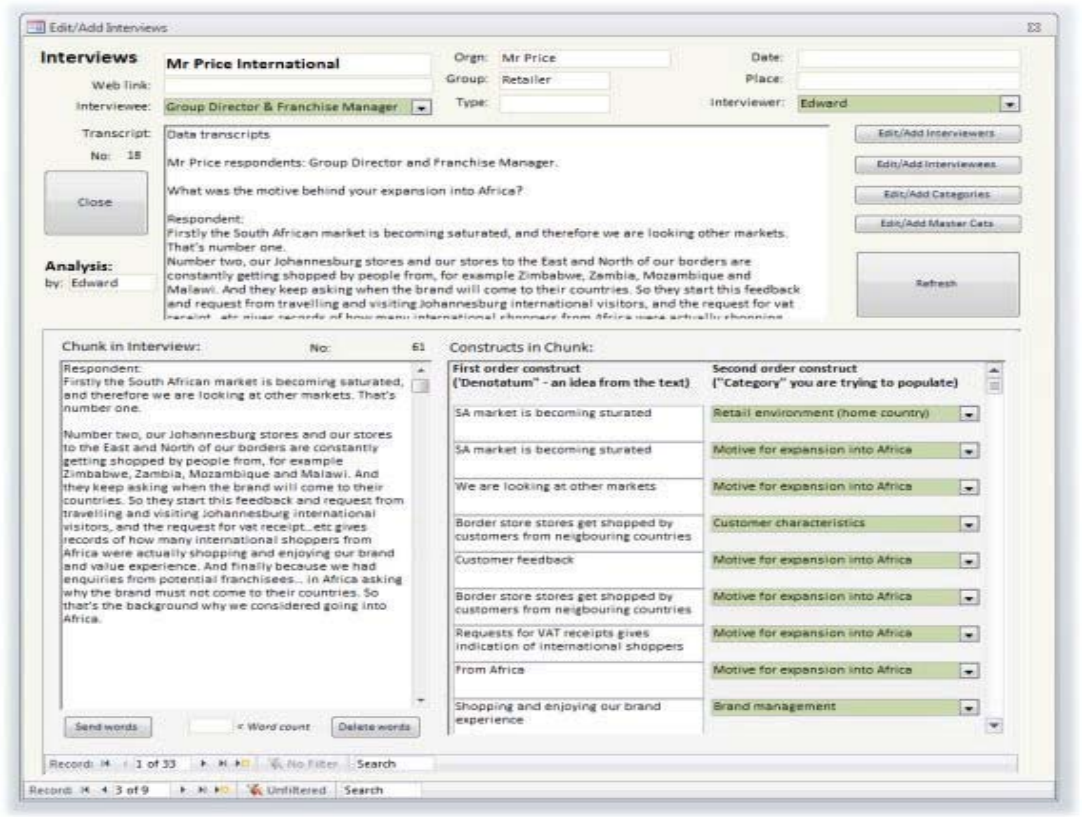

\section{Results}

The analysis of data focused on the characteristics of the retailers, the characteristics of the target countries, and the characteristics of the entry modes. The data is summarised according to the case study companies and the categories. The characteristics of the five retailers studied, and the characteristics of their target countries and possible entry modes, 
and the resultant choice of entry mode, are demonstrated in Table 3. The analysis of the interviews resulted in 72 lowlevel working categories and 1570 constructs, but only nineteen of the 72 categories were relevant to the three high-level categories and were therefore selected for interpretation. Figure 3 illustrates the 19 categories based the count of "denotata" or constructs.

Figure 3: A graphical extraction of the low-level categories

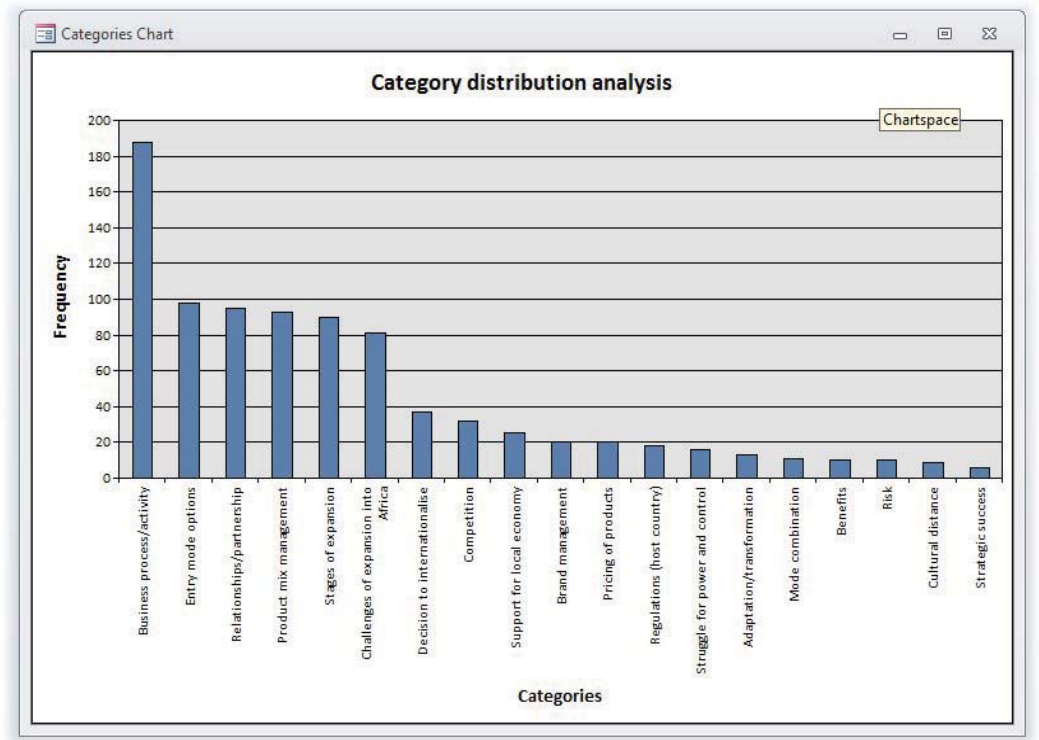

Figure 1 shows very clearly that the overwhelming interest of the respondents was to talk about the business processes that pertain to their retailing activities, even when talking about their expansion into Africa. The cluster of categories concerned with entry mode, partnership arrangements, product mix and the stages and challenges of entry into Africa. What is perhaps most interesting is the relative unwillingness (or inability) to talk about critical issues such as strategy, culture, risk benefits, and the more complicated aspects of mode combination.

This rather mixed view of things becomes much simpler when the low-level view in Figure 1 is replaced by the higher level view of "master" categories (a term used in the analysis) where the three principal areas of interest are clearly ranked according to the extent of respondents' interest in talking about them (as seen through the coding at the lower level, and as summarised in Table 3). Figure 4 shows a frequency distribution of the master categories, based on the count of denotata.

Figure 4: The main categories of the interviews

Master category distribution analysis

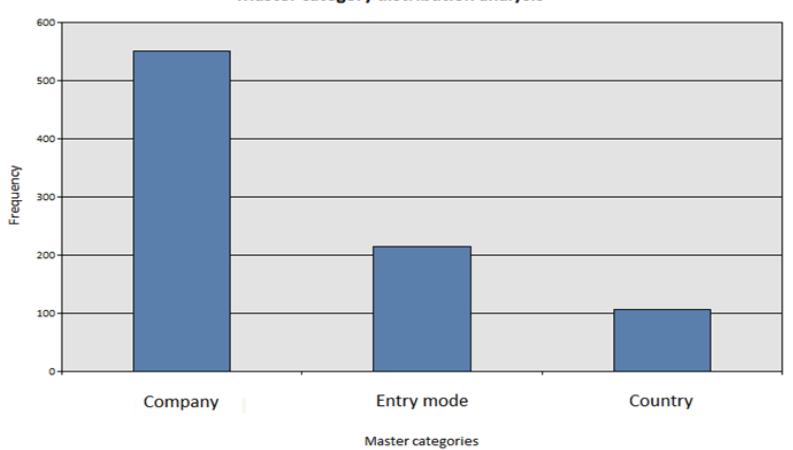


Here we see that respondents were most concerned to talk about the situation within their own companies, then the mode of entry issues, and finally the qualities and characteristics of the targeted countries.

Table 3: Patterns of entry mode choice (at the time of the enquiry)

\begin{tabular}{|c|c|c|c|c|}
\hline $\begin{array}{l}\text { Characteristic } \\
\text { Retailer }\end{array}$ & Company characteristics & Country characteristics & Mode characteristics & Mode choice \\
\hline Shoprite & $\begin{array}{l}\text { - High brand value } \\
\text { - The investment in Africa has reached } \\
\text { maturity stage } \\
\text { - Structure is set up } \\
\text { - Invitation by target country } \\
\text { governments } \\
\text { - Follows the rules of the land } \\
\text { - Source fresh produces locally } \\
\text { - Deliberately promoting SA products } \\
\text { - No sharing of wealth }\end{array}$ & $\begin{array}{l}\text { - Sustainable income } \\
\text { - Incoming of global retailers } \\
\text { - Did not for see the competition } \\
\text { coming } \\
\text { - The spread of DSTV } \\
\text { - Difficulties with regulations } \\
\text { - No involvement in politics } \\
\text { - Lack of formal retail space and } \\
\text { problem with land ownership }\end{array}$ & $\begin{array}{l}\text { - Franchisee will be supplied } \\
\text { the products } \\
\text { - Franchisee will add mark-up } \\
\text { - No middlemen or franchisees } \\
\text { - Franchising is not working for } \\
\text { - Sompetitors } \\
\text { - Successful with own stores }\end{array}$ & - Wholly owned stores \\
\hline Pick n Pay & $\begin{array}{l}\text { - Lack of market knowledge } \\
\text { - International experience } \\
\text { - Cautious approach } \\
\text { - Late comer } \\
\text { - Stocking local products } \\
\text { - Eager to grow local entrepreneurs }\end{array}$ & $\begin{array}{l}\text { - Capitalizing on competitors } \\
\text { mistakes } \\
\text { - Late advantage } \\
\text { - Market difference } \\
\text { - Lack of understanding of the market }\end{array}$ & $\begin{array}{l}\text { - Flexibility in terms of being } \\
\text { able to cope implement } \\
\text { strategies } \\
\text { - Easy to garner scale and } \\
\text { growth }\end{array}$ & $\begin{array}{l}\text { - Not fixed on any } \\
\text { particular mode } \\
\text { - Entry mode depends } \\
\text { on the country } \\
\text { - Wholly own stores } \\
\text { - franchising }\end{array}$ \\
\hline Woolworths & $\begin{array}{l}\text { - Protection of the brand } \\
\text { - Target middle - upper income brackets } \\
\text { - Testing the markets } \\
\text { - Emphasis on the approach } \\
\text { - Logistics is a challenge }\end{array}$ & $\begin{array}{l}\text { - Different country identities } \\
\text { - Different view to big brother } \\
\text { - DST helps promote the products } \\
\text { - Regulations are country specific } \\
\text { - Restrictions on certain modes }\end{array}$ & $\begin{array}{l}\text { - Flexibility } \\
\text { - Risk management }\end{array}$ & $\begin{array}{l}\text { - Own stores } \\
\text { - Franchising } \\
\text { - Distribution } \\
\text { arrangements }\end{array}$ \\
\hline Foschini & $\begin{array}{l}\text { - Unwilling to change product range } \\
\text { - Protection of the brand } \\
\text { - Lacks appropriate structure } \\
\text { - Small store sizes } \\
\text { - Try and error } \\
\text { - Seasonal products }\end{array}$ & $\begin{array}{l}\text { - Need to adapt to market } \\
\text { - Lack of quality products locally } \\
\text { - Affordability of fashion clothing } \\
\text { - Difficulty in terms of different } \\
\text { regulations and other market } \\
\text { conditions }\end{array}$ & $\begin{array}{l}\text { - Balance between risks and } \\
\text { profits } \\
\text { - Where the risks are too high, } \\
\text { we will go Franchise }\end{array}$ & $\begin{array}{l}\text { - Franchising } \\
\text { - Wholly own stores }\end{array}$ \\
\hline Mr Price & $\begin{array}{l}\text { - } \text { Brand protection } \\
\text { - Lack of market knowledge } \\
\text { - Request from potential franchisee, and } \\
\text { - } \text { customers } \\
\text { - Humble approach } \\
\text { - } \text { Prodk with highly networked partners } \\
\text { Pron the country }\end{array}$ & $\begin{array}{l}\text { - Level of Westernization and } \\
\text { sophistication of the customer } \\
\text { profile } \\
\text { - Culture of the country } \\
\text { - Market complexity } \\
\text { - competition }\end{array}$ & $\begin{array}{l}\text { - Risk } \\
\text { - Capital investment }\end{array}$ & - Franchising \\
\hline
\end{tabular}

\section{Discussion}

\subsection{Company, mode and country issues}

The opening of wholly owned stores, and mergers and acquisitions are said to be preferred by internationalising retailers, especially those embarking on the "global strategy" approach due to its flexibility in allowing for control and management involvement in the foreign operations (Menipaz \& Menipaz, 2011:358). This also increases the return on the retailers' investments, although full ownership also leads to the retailers having to take full responsibility for all the risks. According to the analysis summarised in Table 3, Shoprite is the only company among the retailers studied to be opening wholly owned stores as its sole entry mode for expansion across Africa.

You know, from 1994 to 2010, in 16 years the share price is sitting at over R90. So it was the right decision not to franchise or share the wealth with people who didn't contribute to the business [Shoprite respondent].

This decision and other items (Table 3) which characterise Shoprite's approach to Africa-wide expansion, make the retail chain feel that it can have absolute control over its international operations, and apply the same "modus operandi" everywhere. In so doing Shoprite is concerned with sustainable income in the country of target, and land or 
retail properties so as to establish its own stores. When it comes to entry mode, the retailer believes franchising does not work, and as a general experience, limited partnership and acquisition targets. As Games (2008) indicates, the lack of suitable acquisition targets is due to the largely informal nature of retailing is most African countries. This could have possibly been an easier route to fast-tracking the expansion of the South African retailers within the continent. Shoprite grew in its home market through mostly acquisitions, and partly in Zambia, where it purchased the state-owned retail stores in the mid-1990s.

The other extreme case is Mr Price, which is also carrying out its international expansion project by means of franchising only. According to Table 3, the clothing retailer is characterised by brand protection, lack of local knowledge, a humble approach, and requests from potential business partners and customers from neighbouring countries. These company characteristics, especially the lack of local knowledge and the need to protect the brand have driven Mr Price to be concerned about the competition, complexity, culture and customer profiles of the target countries. The following quote exemplifies this:

\begin{abstract}
We could have gone with a full corporate store, but we don't have local know-how, and we have no idea how to be competitive in those markets; and thirdly until we know those countries our investors will be concerned about giving their money out. So the other options will be possibly a joint venture or a partnership of some kind [Mr Price respondent].
\end{abstract}

Further, the clothing retailer measures these against the risks and resource commitment involved in the entry mode, when it comes to choosing one. Quinn and Alexander (2002) assert that the local partner understands the local market conditions better than the franchisor and is, therefore, better placed to handle local issues such as culture, language barriers, bureaucracy, red tape and other political problems. This entry mode also requires limited resources and lowers risk (Sternquist, 2007).

The rest of the retailers have used or are intending to use different entry modes for different countries, based on their unique characteristics and their experiences or perceptions about the target countries, and entry mode options. Pick $\mathrm{n}$ Pay for example is following Shoprite but lacks the knowledge of local markets, and therefore is very cautious. However, it is enjoying a latecomer advantage by having to learn from the mistakes of its main competitor, Shoprite, which is one of the pioneers of this phenomenon. As a result, Pick $n$ Pay is flexible in its approach, studying targets countries and choosing the best applicable entry mode.

So far Pick n Pay has chosen two main entry modes, wholly owned stores and franchising, with an indication of mixing the two modes at later stages of the internationalisation process, and in different countries. The sequence of the use of different entry modes and their combinations thereafter is dependent on the characteristics and the mode itself as perceived by the retailer.

Woolworths and Foschini are both protective of their brands, and are both concerned about target country regulations and risks associated with modes when it comes to entry mode choice. Woolworths have used franchising, distribution arrangements, wholly owned stores, and later joint ventures in different countries. Foschini, on the other hand, would open wholly owned stores and franchises. However, there are other distinct characteristics of Foschini that are not evident in the case of Woolworths, including small size stores, strategy of "trial and error", and the fact that it lacks the appropriate managerial structure to handle the expansion. These characteristics also play a role in the way in which the clothing retailer considers its entry mode choice.

\title{
5.2 Entry mode choice
}

In general, the main entry modes used by the retailers studied have been based on operating their own stores and international franchising. However, other entry modes including partnerships or joint ventures and distribution arrangements were used as complementary modes in some instances. The retailers' differences became apparent in their entry choice. While the food retailers were found to be opening their own stores, the clothing retailers were more prone to use franchising. Moreover, it was found that the different entry modes were used or even combined in entering different countries and sometimes at different stages and times.

Overall, understanding the African markets and country differences, managing logistics, lack of suitable retail space, finding suitable partners, finding experienced retail managers, and understanding different financial and customs systems all combine to make this process of internationalisation complex. All these affect the choice of entry which needs to be managed carefully, as it is becomes a trade-off between risks and returns (Kathuria, Joshi \& Dellande, 2008). 


\section{Conclusion and Implication for Management}

Differences between the 54 African countries make entry into the retail markets difficult. Most retailers from South Africa (the majority of which have only limited international experience) struggle to sufficiently understand the differences in the markets, and now face potential and actual competition from new global players. This, coupled with the generally informal retail systems across the continent, the lack of suitable formal retail spaces, underdeveloped production systems for supply and lack of suitable partners all make the process of retail internationalisation far more complex than traditionally imagined. Yet, Africa is now home to vibrant and growing consumer markets within which retail activity can thrive.

There is a risk that South African retailers moving into Africa will be seen as aggressive, forceful and uncaring about their impact on established traditional retail activity. This study has shown that proper consideration of the mode of entry can mitigate the serious risks that arise from this perception, and can lead to a better kind of business for all concerned.

\section{References}

African Development Bank. (2007). High Level Panel for the African Development Bank. Investing in Africa's future: The ADB in the 21st century. Available: http://www.afdb.org/fileadmin/uploads/afdb/Documents/publications/27842402-en- hlp-report-investingin-africas-future.pdf (15 November 2010).

Anderson, E. \& Gatignon, H. (1986). Modes of foreign entry: A transaction cost analysis and propositions. Journal of International Business Studies, 17 (3), 1-26.

Asgari, M., Ahmad, S.Z. \& Gurrib, M.I. ( 2010). Explaining the internationalisation process of Malaysian service firms. International Journal of Trade, Economics and Finance, 1 (1), 68-73.

Bleby, M. (2011). Local industry key to Massmart deal. Business Day. Available: http://www.businessday.co.za/articles /Content.aspx?id=138028 (24 March 2011).

Cliquet, G. (2000). Plural forms in store network: a model of store network evolution. The International Review of Retail, Distribution and Consumer Research, 10(4): 369-387.

Crush, J. \& Frayne, B. (2011). Supermarket Expansion and the informal food economy in Southern African cities: Implications for urban food security. Journal of Southern African Studies, 37(4): 781-807.

Dakora, E.A.N., Bytheway, A. \& Slabbert, A. (2010). The Africanisation of South African retailing: A review. African Journal of Business Management, 4(5): 784-754.

Dakora, E.A.N. (2012a). Exploring the fourth wave of supermarket evolution: concepts of value and complexity in Africa. International Journal of Managing Value and Supply Chains, 3, (3): 25-37.

Dakora, E.A.N. (2012b). Strategic Approaches to the Africanisation of South African retail businesses. Unpublished D.Tech. Thesis, Cape Peninsula University of Technology, Cape Town.

Dawson, J. \& Mukoyama, M. (2006). The increase in international activities by retailers. In Dawson, J., Lark, R. \& Mukoyama, M. (eds). Strategic issues in international retailing, Routledge: London.

Deloitte. (2011). Leaving home: global powers of retailing 2011. Stores, [Online] Available: http://www.deloitte.com/assets/DcomPortugal/Local\%20Assets/Documents/CB/pt\%28en\%29_cb_gpr2011_17012011.pdf (14 April 2011).

Dunning, J.H., Pak, Y.S. \& Beldona, S. 2007. Foreign ownership strategies of UK and US international franchisors: An exploratory application of Dunning's envelope paradigm. International Business Review, 16: 531-548.

Dunning, J.H. (1988). The eclectic paradigm and international production: a restatement and some possible extensions. Journal of International Business Studies, 19 (1): 1-31.

Dunning, J.H. (2000). The eclectic paradigm as an envelope for economic and business theories of MNE activity. International Business Review, 9: 163-190.

Dunning, J.H. 2001. The eclectic (OLI) paradigm of international production: Past, present and future. International Journal of the Economic of Business, 8 (2): 173-190.

Games, D. (2008). The South African retail sector in Africa. In Grobbelaar, N. \& Besada, H. (eds). Unlocking Africa's potential: the role of corporate South Africa in strengthening Africa's private sector, SAllA: Johannesburg.

Ghisi, F.A., da Sylveira, J.A.G., Kristensen, T., Hingley, M. \& Lindgreen, A. (2008). Horizontal alliances amongst small retailers in Brazil. British Food Journal, 110(4/5): 514-538.

Grünhagen, M., Dorsch, M.J. \& Wollan, M.L. (2008). Recall of autobiographical memory: a longitudinal analysis of franchisee experts. International Enterprise Management Journal, 4:19-33.

Hammersley, M. \& Gomm, R. (2000). Introduction. In Gomm, R., Hammersley, M. \& Foster, P. Case study method: Key issues, key texts. London: Sage.

Hoffman, R.C. \& Preble, J.E. (2004). Global franchising: current status and future challenges. Journal of Services Marketing, 18(2): 101-113.

Hollensen, S. (2007). Global marketing: a decision-oriented approach. 4th ed. Prentice Hall: London. 
Javalgi, R.G., Deligonul, S., Dixit, A. \& Cavusgil, S.T. (2011). International market reentry: A review and research framework. International Business Review, 20: 377-393.

Johanson, J.A.N. \& Wiedersheim-paul, F. 1975. The internationalization of the firm - Four Swedish cases. The Journal of Management Studies, 7(149): 20-37.

Kathuria, R. Joshi, M.P. \& Dellande, S. (2008). International growth strategies of service and manufacturing firms: the case of banking and manufacturing industries. International Journal of Operations and Production Management, 28(10): 968-990.

Kotabe, M. \& Helsen, K. (2008). Global marketing management. 4th ed. Hoboken, NJ: Wiley.

Lukas, E. (2007). Dynamic market entry and the value of flexibility in transitional international joint ventures. Review of Financial Economics, 16: 91-110.

Mathews, J.A. (2006). Dragon multinationals: new players in the 21st century globalisation. Asia Pacific Journal of Management, 23:527.

Menipaz, E. \& Menipaz, A. (2011). International business: theory and practice, Sage: London.

Miller, D. (2006). Spaces of resistance: African workers at Shoprite in Maputo and Lusaka. Africa development, 3(1): 27-49.

Miller D (2008). 'Retail renaissance' or company rhetoric: the failed partnership of South African Corporation and local suppliers in Zambia. Labour, capital and society, 41(1): 34-55.

Moore, C.M. \& Fernie, J. (2004). Retailing within an international context. In Bruce, M., Moore, C.M. \& Birtwistle, G. (eds). International retail marketing: a case study approach, Heinemann: Oxford.

Myers, H. \& Alexander, N. (2007). The role of retail internationalisation in the establishment of a European retail structure. International Journal of Retail and Distribution Management, 35(1): 6-19.

Narula, R. 2010. Keeping the Eclectic Paradigm simple. The Multinational Business Review, 18(2): 35-49.

Nordås, N.K., Grosso, M.G. \& Pinali, E. (2007). Market structure in the distribution sector and merchandise trade. OECD Trade Policy Working Papers, no. 68, OECD Publishing. Doi:10.1787/244328264654. Available: http://www.olis.oecd.org/olis/2007doc.nsf /frerefcorplook/nt00005be2/\$fil e/jt03239641.pdf (04 June 2010).

Pahl, N. \& Richter, A. (2008). International strategic alliances and cross-border mergers \& acquisitions, Norderstedt: Grin Verlag.

Park, Y. \& Sternquist, B. (2008). The global retailer's strategic proposition and choice of entry mode. International of Retail \& Distribution Management, 36(4): 281-299.

Pederzoli, D. (2006). Conception and test of a comprehensive model of international strategy for retail companies. The International Review of Retail, Distribution and Consumer Research, 16(4): 415-431.

Picot-Coupey, K. (2006). Determinants of international retail operations mode choice: Towards a conceptual framework based on evidence from French specialised retail chains. International Review of Retail and Consumer Research, 16(2): 215-237.

Quinn, B. \& Alexander, N. (2002). International retail franchising: a conceptual framework. International Journal of Retail and Distribution Management, 30(5): 264-276.

Rasiah, J., Gammeltoft, P. \& Jiang, Y. 2010. Home government policies for outward FDI from emerging economies: Lessons from Asia. International Journal of Emerging Markets, 5(3/4): 333-357.

Ripollés, M., Blesa, A. \& Monferrer, D. (2011). Factors enhancing the choice of higher resource commitment entry modes in international new ventures. International Business Review, doi:10.1016/j.ibusrev.2011.07.007.

Schutz, W.C. (1959). On categorising qualitative data in content analysis. Public Opinion Quarterly, 22(4): 503-515.

Slangen, A. \& Hennart, J.F. (2007). Greenfield or acquisition entry: a review of the empirical foreign establishment mode literature. Journal of International Management, 27:403- 429.

Sternquist, B. 2007. International retailing. 2nd ed. Fairchild: New York.

Strauss, A. \& Corbin, J. (1998). Basics of Qualitative Research. Sage: Thousand Oaks.

Weatherspoon, D.D. \& Reardon, T. (2003). The Rise of Supermarkets in Africa: Implications for Agrifood Systems and the Rural Poor. Development Policy Review, 21(3): 333- 355.

Wu, W.Y., Shih, H.A. \& Chan, H.C. (2009). The analytic network process for partner selection criteria in strategic alliances. Expert Systems with Applications, 36:464- 4653.

Yin, R.K. (1981). The case study crisis: Some answers. Administrative Science Quarterly, 26(1): 58-65.

Yin, R.K. (2003). Case study research: design and methods. 3rd ed. Thousand Oaks: Sage.

Yin. R.K. (2009). Case study research: design and methods. 4rd ed. Los Angeles: Sage.

Zhang, Y., Zhang, Z. \& Liu, Z. (2007). Choice of entry modes in sequential FDI in an emerging economy. Management Decision, 45(4): $749-772$.

Zentes, J., Morschett, D. \& Chramm-Klein, I. (2007). Strategic retail management: Text and international cases. Gabler: Wesbaden. 